\title{
The Dilemma of Regional Autonomy "Between Equality of Development and Scramble of Power"
}

\author{
Muhammad Arsy Ash Shiddiqy \\ Faculty of Social and Political Science, Islamic University of Riau \\ Pekanbaru, Indonesia \\ Student of Doctoral Program at Universitas Padjadjaran \\ arsyshiddiq@gmail.com
}

\begin{abstract}
Regional Autonomy is not a strange thing we hear. People often yelling out his name. However, behind it big names there are many dilemmas arise, for example is the Equality of Development and scramble of Power. In essence Regional autonomy is organized for the equitable distribution of development throughout the country, but in fact, the implementation of regional autonomy instead used as a venue for scramble of power by the hunters of position and assets. Entering the era of regional autonomy with the enactment of constitution no. 22 of 1999 which replaces no. 5 Year 1974, Gong of Regional Autonomy began to roar on this archipelago earth. Fifteen year more running, there is a unique phenomenon that interesting to be our concern, which is the spreading of regional expansion and the number of regional heads involved in corruption cases. Although today the government imposed a moratorium on regional expansion but it has not enough inhibited the political lust of the power hunters not to compete for seeking of position. The implications absolutely are the equality of development as a goal can no longer be achieved. Started from this issue the author wants to serve an article about the dilemma of Regional Autonomy. Is the goal of equitable development has been achieved or even the opposite of power scrambles that became the tagline of Regional Autonomy.
\end{abstract}

Keywords- Regional Autonomy; Equality of Development; Scramble of Power

\section{INTRODUCTION}

Regional Autonomy is the transfer of authority from the central government to the local government to take care of its own household affairs based on the initiative and aspirations of its people within the framework of the unitary state of the Republic of Indonesia. with the existence of decentralization then emerged autonomy for a local government.

Decentralization is actually a term in organization that is simply defined as the transfer of authority. In relation to the Indonesian system of governance, recently the decentralization has often been linked to the governance system because decentralization has now led to change the paradigm of governance in Indonesia. Decentralization can also be interpreted as the transfer of responsibility, authority, and resources (funds, human beings etc.) from the central government to the local government. The rationale behind it is the desire to move decision-making closer to those who feel the direct impact of programs and services designed and implemented by the government (1). This will increase the relevance of public services to the needs and conditions of local communities, while still pursuing the goals to be achieved by the government at the regional and national levels, socially and economically.

The principles of Regional Autonomy consist of: 1 . Centralization principle is the centralization of the entire administration of the State government with the central government. 2. Decentralization principle is all central government authority delegation to the local government. 3 . Deconcentration principle is the delegation of authority from government to the governor as a representative of the government and the central device in the region. 4. Assistance Principle is a principle that states participate in the implementation of government affairs assigned to local governments with an obligation to account for those who give the task. The purpose of granting regional autonomy as follows: 1. Improving the public services are getting better. 2. Development of democratic life. 3. Justice. 4. Equitable development. 5. Maintaining a harmonious relationship between the Center and the Regional and between regions in the framework of the unity of Indonesia. 6. Encouraging for community empowerment. 7. Growing initiative and creativity, enhancing community participation, developing the role and function of the Regional House of Representatives(2).

Post-independence, the regulation on regional autonomy has been amended 9 times, as follows Constitution No. 1 of 1945, Constitution Number 22 Year 1948, Constitution Number 1 Year 1957, Presidential Decree Number 6 Year 1959, Constitution Number 18 Year 1965, Constitution Number 5 Year 1974, Constitution Number 22 Year 1999, Constitution Number 32 Year 2004 and last Act No.23 of 2014. The course of regional autonomy post-Reformation is long and winding. The spirit of freedom to be voiced "local" increasingly reveals, seen from the increasing number of areas that become New Autonomous Region (DOB) even though the district, city, and provincial levels. Inevitably, 
this amorphous stretch is perpetuated by the government by setting the day of Regional Autonomy every 25 April.

\section{SCOPE OF QUESTION}

Based on the explanation above, this article will focus on observing the dilemma on regional autonomy, is the regional autonomy can bring the prosperity for people through equality of development or just only to fulfill the political lust for the seeker of power in the local government. this paper will describe the dilemma that emerge in regional autonomy, and this paper also explain why the regional expansion as a impact of autonomy become a venue for the seeker to scramble of power. Thus, this paper is limited to the following issues:

a. why regional autonomy does not always bring prosperity to the community?

b. how can the regional expansion become a venue for a scramble of power?

\section{DISCUSSION}

\section{A. Equality of development in Regional Autonomy}

Regional autonomy is one of the main discourses that fought for when reformation are called. Where during power of new order implements a system of centralization in all aspect. which are government sector, economy, politics to the cultural level. So what happens is the inequality of development between the Java and other islands. This gap is what makes some regions want to break away from the unitary state of the Indonesian republic (NKRI). This is one of the reasons why people are calling for reformation to demand justice, development must be implemented equally throughout Indonesia. So the people of Indonesia from Sabang to merauke could feel the real independence. Indeed, independence is not merely an occupation but also enjoys a quality infrastructure, education and public services must be able to reach up to the lowest levels.

Conflict of regional autonomy is not only happening in the leadership of new order. But has been far up since the leadership of the old order with the leadership of first Indonesian president Ir. Soekarno. Gap conflict between central and regional is causing rebellion Revolutionary Government of the Republic of Indonesia (PRRI), the struggle of the universe peoples (PERMESTA), and others. The echoes of development are heard in various cities and villages of this country, from the central and regional levels. Various development programs are encouraged and socialized. What a remarkable progress when this is done well. However, strict supervision needs to be done, because this country seems still difficult to find people who really hold the mandate well (3).

Therefore, if the supervision done by the central government and the authorities is not good then the purpose of development will not be implemented with the maximum. Regional development is a process whereby local governments and communities manage existing resources and form a partnership between local governments and the private sector to create new jobs and stimulate the development of economic activity in the region.

P2DTK, Accelerated Development of Disadvantaged and Special Areas, is an innovative pilot program initiated by the Government of Indonesia in August 2005 and is designed to address governance and policy problem in 51 of the poorest districts across Indonesia. P2DTK is based on a number of other successful community development projects, such as the district Development Program (KDP), to align bottom-up planning procedures with newly empowered district governments (4).

\section{A. The Regional Expansion as A Venue for Scramble of Power}

Seventeen years post-reformation a lot of political and governmental advancement in the country. One of them is the regional expansion. Data from Ministry of Home Affairs show that during the period of 1999-2016 there were 205 new districts expansion, consisting of 7 provinces, 164 districts and 34 cities. Coupled with 11 New Autonomous Regions (DOB) which was recently inaugurated. Currently, it has been waiting for five DOB proposals that will be discussed in the next session of the House of Representatives. All of the expansion proposal coming from right of initiative of the DPR, while on the other hand the government is still consistent with the spirit of the moratorium.

Indeed, the expansion of a region into several new autonomous regions aims to improve people's welfare, equality of development, and improving the quality of public services. Without it, the expansion of the region will be merely the fulfillment of political lust and political commodities that benefit for political elites, but miserable the society. It is common knowledge that regional expansion is synonymous with providing vacancies for various political positions, from heads of regions to house of district representation (DPRD) members. Even promotional opportunities are open to bureaucrats who want to emigrate from parent regions or other areas to the new region of expansion.

As long as the proposal on expansion fulfills the requirements, as stated in Article 5 paragraph 1 of constitution Number 32 Year 2004, which is administrative, technical, and physical requirements of the territory, then the district expansion is feasible. In essence, the new autonomous regions will bring closer public services and creates community welfare. the large district will be difficult to create equitable development. Especially if the district does not have adequate budged. Not surprisingly, many people request that should be expansion because the district never progressed after decades of birth. We can see how it used to be in 2000, they separated from Banten region of 
West Java and Bangka Belitung separating from South Sumatra. The far range of control has make the wheel of development in Banten and Bangka Belitung far behind (5).

So what should the central government do? government should be firmly to the House of Representatives in the moratorium on district expansion until the completion of the revision of constitution 32/2004 on Regional Government, as well as revising PP 78/2007 regarding the political articles. The government would be expected not to hesitate to re-combine or remove the district expansion that is considered failed. in same time the implementation of the 2010-2025 Regional Design (Desertada) which contains the ideal number of provinces, districts and cities in Indonesia. Until 2025, the government plans to add only 11 provinces and 54 new districts / cities. In addition, the government should consistently impose a 5-year transition period for prospective district expansion. During that time the new district was an administrative territory and remained under its parent territory. The establishment of a new Autonomous Region (DOB) is possible to break the range of bureaucratic control. That way, the development program will be more quickly perceived by the community. The realization of public service is one indication. Unfortunately, many of the practices of regional autonomy in the Reformation Era are ignorant the needs of the people. Freedom of expression and managing the assets of the region, by some, especially the political elite actually become a boomerang for the people. Autonomous regions are usually generated a lot of innovation in the district to be glimpsed center, especially in the provision of assistance. Infrastructure development was intensified for the sake of a regional ownership identity. However, not a few of these developments stag in the middle of processing due to various factors, related to the interests of the political elite, bureaucratic coordination is not slick, till the game with the project contractors. Instant development such as that make peoples suffering in the region. there is the drag of authority between local and central still happens often to show power fangs. Various demands of the district expansion at this time tend to be only the act of the political elite in order to gain power, without considering the impact and various problems that will be faced.

Regional autonomy has a fundamental changes in the bureaucratic system of government between central and regional, as well as changes in the political system. Direct local elections are logical consequences when the regions are given the authority and great power to manage their respective regions. Under these circumstances, the political constellation of the region will increase as a means of fighting over the highly autonomous regional power. expansion regional lust seems to have no signs of subsiding in the next few years, everywhere discussed and struggled with excitement, even rarely referred as the price of death. Thats mean there is no bargaining. All mantras that are considered efficacious be readed. Various custom knacks were installed to beautify the proposal. Everyone deserves to be involved in strengthening the line. Without shyness all the way to be done.

In the middle of the poor creativity, many people who believe that the regional expansion is the most appropriate recipe to immediately cure various diseases of poverty, backwardness and underdevelopment that have been incurred for years without incurable. eRegional expansion is considered telling to immediately bring instant economic prosperity for the people in the region. Because, like or dislike, agree or disagree, in various places of this country there are still many corners that have not been touched development. Portraits of the reality of poverty and lag are often published by various media, such as pictures of people suffering from hungry busk, children who lost the joy of childhood for having to work for life, beggars and scavengers, children in school uniforms who had to cross the river through dangerous bridges, poor mothers forced to work hard, village children who have to learn with floodlights, slum areas are flooded, schools like goat pens, and so on. Too many to be mentioned one by one (6).

To be short story, inequality development. There are areas that many times each year got a lot of development budget, otherwise there are areas that have not been touched by development, Here's the problem. So, in order to be equality distribution of development comes a simple thought, just looking for easy way which is the regional expansion. With the regional expansion the span of control being shortened, the power distance between leader and the people can be brought closer so that communication is easier.

Therefore there is nothing wrong with the expansion of the region. The establishment of new autonomous regions will surely accelerate the development of infrastructure, such as roads, bridges, electricity, clean water and telecommunications. This infrastructure is needed by the community to support the community economy down to the village. If the transportation infrastructure is good (crossdistrict, cross-district and cross-village), the people's economy will grow by itself, the community's independence will be built.

\section{CONCLUSION}

One of the most important thing of reformation is the redistribution of power from a centralized system to a decentralized through regional autonomy. However, it seems that regional autonomy has not been fully implemented as expected. Even the power in the region gave birth to small kings who actually alienated the interests of the people. The emergence of conflict and violence in the region is one proof of local government failure to understand the condition of the community. This fact at the same time inhibits the steps and policies taken by the central government. National programs that should be enjoyed by the community are constrained by the interests of regional 
elites, including deviations likes corruption, collusion and nepotism. This all because the distribution of power (regional autonomy) is fully understood as the goal not the way to bring the state closer to the society. Regional autonomy has become an elite political bloc in the region to perpetuate the interests of its power, the implementation of the main goal of regional autonomy is not maximized which is to bring the state closer to its people. Regional autonomy is no more than power scramble at the regional level and the people do not feel the maximum benefit.

The centralized development and governance policy, then changed to regional autonomy in line with the Reformation. But seventeen years of the Reformation passed, regional autonomy which granted the right, authority and duty to govern and administer its own governmental affairs, has not succeeded in answering the problem of lagging a number of regions within an Autonomous Region. On the other hand, constitutional reformation has made the election of regional heads based on the direct election system by the local people concerned. But the demographic reality shows that the isolation of a number of territories within a region makes the region insignificant as a pocket of votes in the electoral process of regional heads, which greatly emphasizes the practicality of politics only. Thus many regions in Indonesia seem to be trapped in the isolation of development and politics, and continue to lag behind (7).

Expansion of the region will also be one of the best moments to grow the economy in that area. With the approval of the New Autonomous Region (DOB), it is hoped that center of government which will be followed by the growth of economic centers, can be the best means to focus the policies that need to be taken to create a justice and prosperous society. Do not let regional expansion become a political commodity and claimed for several parties only. which mean the whole of region is not ready for expansion for various reasons, but because of the political lust for power that is so great, the region is forced to be expanded (8).

\section{REFERENCES}

[1] Hasibuan, Albert. 2002. Otonomi Daerah Peluang dan Tantangan. Jakarta : Pustaka Sinar Harapan

[2] Carmines, Edward G and Robert Huckfeldt, "Political Behavior : An Overview. In Robert E. Goodin dan Hans Dieter Klingemann (eds). A New Handbook of Political Science, New York : Oxford University Press Inc, 1996, pp. 223-244

[3] Hooghe, Marc, "Budaya Politik", in Ishiyama, John T and Breuning, Marijke (eds). Ilmu Politik : Dalam Paradigma Abad Ke-21 Sebuah Referensi Panduan Tematis, Penerjemah: Ahmad Fedyani Saefudin, Jakarta : Kencana Prenada Media Group, 2013.

[4] Berelson, Bernard, "The Structure of Political Beliefs", in Heinz Eulau et als., (Eds), Political Behavior : a reader in theory and research. Macmillan Company, New York. 1972, pp. 107-115.

[5] Riwu Kaho, Josef, 1988, Prospek Otonomi Daerah di Indonesia, Jakarta, PT. Raja Grafindo Persada.
[6] DR. Kaloh J, 2007, Mencari Bentuk otonomi Daerah, Suatu Solusi Dalam Menjawab Kebutuhan Lokal Dan Tantangan Global, Jakarta, Rhineka Cipta. Deddy Supriady Bratakusumah \& Dadang Solihin. 2004. Otonomi Penyelenggaran Pemerintahan Daerah. Jakarta : PT Gramedia Pustaka Utama.

[7] Rozali Abdullah. 2007. Pelaksanaan Otonomi Luas dengan Pemilihan Kepala Daerah Secara Langsung. Jakarta : PT Raja Grasindo.

Website-based resources

[8] http://susisitisapaah.blogspot.com/2011/03/sejarah-perkembanganotonomi-daerah-di.html

[9] http//:republikaonline-pemekaranwilayah.htm. diakses tanggal 20 Maret 2016

[10] www. http// : Pemekaran daerah dan kesejahteraan masyarakat.htm. diakses tanggal 20 Maret 2016 